\title{
PENGGUNAAN MEDIA BAHAN ALAM UNTUK MENINGKATKAN KREATIVITAS ANAK
}

\author{
Nadia Fauziah \\ e-mail: nadyayulianita47@yahoo.com \\ PG PAUD FIP Universitas Negeri Jakarta
}

\begin{abstract}
Abstrak: Penelitian tindakan ini bertujuan untuk meningkatkan kreativitas anak usia 5-6 tahun melalui penggunaan media bahan alam. Penelitian ini dilaksanakan di PAUD Bestari, Gunungsindur, Bogor, pada bulan November 2012. Metode yang digunakan adalah penelitian tindakan yang dllakukan melalui dua siklus yang terdiri atas perencanaan, tindakan, pengamatan dan refleksi. Subjek penelitian adalah anak PAUD Bestari Gunungsindur yang mempunyai masalah pada kreativitas. Berdasarkan persentase ketercapaian hasil penelitian ini, maka dapat dinyatakan bahwa hipotesis diterima. Dengan demikian, disimpulkan bahwa penggunaan media bahan alam dapat meningkatkan kreativitas anak usia 5-6 tahun.
\end{abstract}

Kata Kunci : bahan alam, kreativitas, media

\section{NATURAL MATERIAL MEDIA TO INCREASE THE CHILDREN'S CREATIVITY}

\begin{abstract}
The purpose of this research is to improve the creativity of children aged 5-6 years through natural materials in PAUD Bestari, Gunungsindur, Bogor. The research conducted in November 2012 applied action research approach two cycles. Each cycle consists of planning, acting, observing and reflecting. The research subject were eleven kindergarten children having creativity problems. The final result of the overall data analysis indicates the hypothesis is accepted meaning that using natural materials can improve the creativity of children aged 5-6 years old.
\end{abstract}

Key Word : natural materials, creativity, media

\section{PENDAHULUAN}

\section{Latar Belakang}

Kreativitas tidak akan tumbuh jika anak tidak mendapatkan dukungan dari orang-orang di sekitar anak. Proses dibutuhkan dalam meningkatkan kreativitas anak. Kreativitas tidak akan muncul jika kegiatan atau stimulasi yang diberikan oleh guru tidak bervariasi dan beragam. Kreativitas anak usia prasekolah tak bisa dilepaskan dari faktor bermain. Kehidupan bermain adalah kehidupan anak-anak dan melalui bermain maka memberikan kesempatan kepada anak untuk mengekspresikan dorongan-dorongan kreatifnya. Kegiatan yang diberikan pada anak ini dapat membuat anak berpikir kreatif dan belajar untuk memecahkan masalahnya.

Berdasarkan hasil observasi di PAUD Bestari, peneliti menemukan bahwa di dalam kegiatan pembelajaran yang dilakukan di PAUD ini masih terlihat kurang bervariasi dan menarik. Kegiatan yang dilakukan masih terlalu pasif, sehingga proses menstimulasi kreativitas anak tidak muncul. Guru kurang kreatif dalam menggunakan dan memanfaatkan media. Hal ini menyebabkan anak tidak percaya diri untuk menjawab atau mengajukan pendapatnya.
Kondisi berkurangnya kreativitas pada anak karena lingkungan yang tidak mendukung seperti metode pembelajaran yang digunakan guru dalam kegiatan pembelajaran kurang bervariasi sehingga proses pembelajaran menjadi terasa membosankan bagi anak dan tidak ada dorongan (press) yang memacu kreativitas anak. Dari hasil observasi yang dilakukan di PAUD Bestari, dalam kegiatan pembelajaran guru melatih anak menulis dan mengenal huruf. Salah satu dimensi kreativitas adalah proses. Dalam proses inilah akan menunjukkan suatu kegiatan kreatif atau tidak kreatif. Dari hasil observasi yang dilakukan, guru kurang memberikan kegiatan yang mengasah kreativitas. Anak sibuk dengan lembar kerja menulis. Selesai latihan menulis, guru menyuruh anak berbaris satu per satu membaca buku sebagai latihan membaca. Guru tidak membuat suatu kegiatan kreatif yang dapat membuat anak semangat untuk membaca dan menulis. Dapat dikatakan bahwa proses kreatif ini tidak terjadi. Tidak ada kegiatan eksplorasi, eksperimen maupun tanya jawab yang dapat melatih kreativitas anak.

Mengembangkan minat anak untuk berkreasi sehingga menghasilkan produk yang kreatif tidak Jurnal IImiah VISI P2TK PAUD NI - Vol. 8, No.1, Juni 2013 
ditemukan di PAUD Bestari. Guru memberikan hanya sekali kegiatan berekspresi dan melatih kemampuan motorik dalam seminggu. Seperti dalam kegiatan mewarnai, anak tidak bebas berekspresi menggambar dan mewarnai sendiri untuk menuangkan imajinasinya. Guru menggunakan buku mewarnai yang sudah disediakan sebelumnya.

Lingkungan yang kondusif dapat mengembangkan potensi dan minat anak secara optimal. Tidak adanya sarana dan prasarana yang mendukung membuat kegiatan pembelajaran menjadi terhambat. Salah satunya adalah pentingnya media dalam suatu pembelajaran, namun penggunaan media masih jarang digunakan oleh guru di dalam kegiatan pembelajaran. Guru lebih sering menggunakan lembar kerja sebagai media, padahal media dapat digunakan dengan memanfaatkan lingkungan di sekitar, seperti bahan alam. Bahan alam yang dipakai bisa dari daundaunan, biji-bijian, ranting, batu-batuan dan bahan lainnya yang berasal dari alam. Media pembelajaran dengan bahan alam sebagai bahan dasarnya tidak akan semahal media produksi pabrik atau bahkan tanpa biaya sama sekali.

\section{Rumusan Masalah}

Melihat beberapa permasalahan yang ditemukan di lapangan, maka pertanyaan penelitian dirumuskan sebagai berikut: "Bagaimana meningkatkan kreativitas anak usia 5-6 tahun?". Untuk menjwab pertanyaan tersebut, peneliti berinisiatif memberikan tindakan untuk meningkatkan kreativitas di PAUD Bestari dengan menggunakan media bahan alam. Melalui penggunaan media bahan alam anak dapat mengembangkan kreativitasnya dengan berkreasi menggunakan bahan yang ada dilingkungan sekitar atau alam. Menggunakan media bahan alam akan memberikan pengalaman yang konkret, sekaligus mengenalkan pada anak untuk mencintai lingkungan dan mendekatkan anak pada alam. Berdasarkan berbagai hal tersebut, penelitian akan mengaji apakah penggunaan media bahan alam dapat meningkatkan kreativitas anak usia 5-6 tahun di PAUD Bestari, Gunungsindur, Bogor.

\section{Kajian Teori}

\section{a. Kreativitas}

Kreativitas sering kali dihubungkan dengan kemampuan yang dimiliki oleh orang berbakat, padahal kreativitas dapat tumbuh dari dalam diri setiap orang jika merangsangnya dengan baik. Kreativitas adalah kemampuan untuk menghasilkan atau menciptakan sesuatu yang baru (Baron dalam Triantoro, 2005:15). Pendapat lain mengungkapkan kreativitas yaitu menghasilkan sesuatu yang baru dan dapat dilihat atau didengar oleh orang lain (Frome dalam Abdussalam (2005:14). Kreativitas membuat seseorang untuk menghasilkan sesuatu yang baru. Artinya, kreativitas adalah kemampuan untuk menghasilkan sesuatu yang baru dan orisinil. Seorang anak mempunyai kreativitas yang berbeda-beda untuk menciptakan atau menghasilkan sesuatu sesuai dengan kemampuannya.

Kreativitas mampu membuat seseorang menciptakan atau menghasilkan karya yang baru. Kreativitas menghasilkan ide baru, selain itu dapat menciptakan bermacam-macam hal baru dan asli (Bruce, 2004). Kreativitas merupakan aktivitas imajinasi sehingga ketika produk yang dihasilkan muncul akan bernilai asli (National Advisory Committee on Creative and Cultural Education/NACCCE), 2006:18) . Ide maupun produk baru yang dihasilkan merupakan hasil dari imajinasi dan kreativitas yang ada di dalam diri.

Dari beberapa pernyataan tersebut dapat didefinisikan bahwa kreativitas merupakan kemampuan yang ada di dalam diri seseorang untuk menghasilkan sesuatu yang baru baik berupa gagasan ataupun hasil karya berdasarkan dari hasil imajinasi seseorang.

Di dalam kreativitas terdapat empat dimensi (4P) yang saling berkaitan, yaitu person, press, process dan product. Keempat dimensi ini saling berkaitan, yaitu pribadi (person) kreatif yang melibatkan diri dalam proses (process) kreatif, serta dengan dukungan dan dorongan (press) dari lingkungan, menghasilkan produk (product) kreatif (Susanto dalam Munandar, 2011:112). Kreativitas dimiliki oleh masing-masing pribadi yang unik dan berbeda-beda. Melalui proses kreatif maka akan menghasilkan produk yang kreatif. Kreativitas juga memerlukan dukungan dan dorongan dari dalam maupun dari luar lingkungan. Dengan begitu maka ide-ide akan muncul dan terus berkembang.

Terdapat tiga kondisi dari pribadi yang kreatif, yaitu: (1) keterbukaan terhadap pengalaman, (2) kemampuan untuk menilai situasi dengan patokan pribadi seseorang (internal locus of evaluation), (3) kemampuan untuk bereksperimen dan "bermain" dengan konsep-konsep (Roger dalam Munandar, 2009:32). Dari ketiga kondisi tersebut dapat diartikan bahwa pribadi yang kreatif, dapat secara terbuka untuk membagi pengalaman dengan orang lain. Dapat bersikap sesuai dengan keadaan lingkungan disekitar dia berada. Seseorang yang memiliki pribadi kreatif juga senang dan ingin mencoba dengan hal-hal baru.

Dimensi selanjutnya adalah dorongan. Kreativitas membutuhkan dorongan dari diri sendiri maupun lingkungan. Dorongan merupakan motivasi primer untuk kreativitas ketika individu membentuk hubunganhubungan baru dengan lingkungannya dalam upaya 
menjadi dirinya sepenuhnya (Roger dalam Munandar, 2009:37). Dorongan dibutuhkan dalam rangka untuk mengembangkan potensi didalam diri. Dorongan yang kuat dapat mengembangkan kreativitas. Seperti dorongan dan motivasi yang diberikan dari sekitar anak, yaitu orang tua, guru dan masyarakat.

Proses dalam kreativitas sangatlah penting. Teori Wallas (2009:39) menyatakan bahwa proses kreatif meliputi empat tahap: (1) persiapan, (2) inkubasi, (3) iluminasi, dan (4) verifikasi. Pada tahap persiapan adalah tahap untuk mengumpulkan data dan informasi. Di dalam tahap ini seseorang akan mempersiapkan diri untuk memecahkan masalah. Tahap inkubasi adalah tahap dimana individu seakan-akan melepaskan diri untuk sementara waktu dari masalah yang dihadapinya secara sadar tetapi dalam alam prasadar. Di dalam tahap ini membutuhkan waktu yang tidak menentu. Tahap selanjutnya adalah iluminasi yaitu akan muncul ide-ide atau gagasan untuk memecahkan masalah. Tahap terakhir adalah verifikasi atau tahap evaluasi dimana ide atau gagasan baru yang muncul harus diuji dengan pemikiran yang kritis.

Dimensi yang keempat membahas mengenai produk. Kreativitas seseorang akan menciptakan produk kreatif. Produksi kreatif adalah suatu produksi yang baru dan yang tiada tandingannya, serta dikenal dengan kemampuan untuk memproduksi sesuatu yang baru atau menciptakan hubungan baru terhadap sesuatu yang telah diketahui sebelumnya, dengan syarat sesuatu atau hubungan yang baru itu mempunyai tujuan tertentu dan bermanfaat, serta mampu menutupi kebutuhan bagi individu atau sekelompok orang (Abdulssalam, 2005:32). Artinya, anak dapat menghasilkan karya berupa produk yang inovatif dan orisinil dari hasil pemikirannya yang kreatif.

Jika memiliki kondisi pribadi dan lingkungan menunjang (press) atau lingkungan yang memberi kesempatan/peluang bersibuk diri secara kreatif maka diprediksikan bahwa produk kreativitas akan muncul. Dari penjelasan mengenai 4P menunjukkan bahwa keempat dimensi ini saling berkaitan dan akan menghasilkan produk yang baru pada akhirnya.

\section{Media Bahan Alam}

Bahan alam merupakan bahan atau material yang ada di alam sekitar. Bahan alam terdapat di alam dan ditemukan di tanah atau bagian dari hewan atau tumbuhan (Whittaker, 2004:46) . Bahan alam mudah ditemukan disekitar lingkungan anak. Bahan alam juga terdapat diluar pintu kita atau dapat diperoleh dekat tempat tinggal kita (Miller, 2009:64). Bahan alam merupakan bahan yang tak terbatas dan mudah ditemukan hampir di lingkungan sekitar.
Penggunaan bahan akan mempengaruhi pengetahuan anak, bermain dan mengekspresikan ide. Bahan yang digunakan anak dapat menstimulasi daya kreatif imajinasi anak dan ekspresi artistik (Charney dalam Isenberg \& Jalongo, 2010:279). Penggunaan bahan juga dapat digunakan untuk lebih dari sekali tema atau kegiatan yang akan di pakai dalam berbagai pembelajaran.

Memanfaatkan lingkungan alam akan merangsang bakat dan potensi yang dimiliki anak. Lingkungan alam kaya akan mengembangkan potensi anak dikarenakan: (1) alam bersifat universal dan tidak habishabis, (2) alam tidak dapat diprediksi, (3) alam sangat berlimpah, (4) alam itu indah, alam hidup dengan suara, (5) alam menciptakan banyak tempat dan, (6) alam dapat menyembuhkan dan mengandung kekayaan makanan yang bergizi (Greenman, 2008:4). Melalui alam, anak akan belajar dengan bermain disekitarnya. Lingkungan alam tidak hanya akan berpengaruh terhadap perkembangan tubuh anak, tetapi memberikan pengalaman bermain yang nyata bagi anak.

Dari definisi yang ditemukan media bahan alam merupakan suatu alat interaksi atau berkomunikasi dengan menggunakan bahan yang berada dialam sekitar anak. Memanfaatkan yang ada disekitar alam sebagai media menjadikan anak dapat belajar dengan konkret. Melalui media bahan alam, anak akan diberikan contoh yang nyata dan langsung dalam kegiatan pembelajaran yang berikan.

Bahan alam meliputi batang, ranting, daun, batu, biji-bijian, pasir, lumpur dan air. Anak dapat melakukan eksperimen dan ekplorasi dengan menggunakan bahan alam (Isenberg \& Jalongo, 2010:282). Anak secara tidak langsung akan mengenal benda-benda atau bahan-bahan yang ada disekitarnya seperti pasir, tanah, kulit jagung, biji dari pohon cemara, batu bata, beragam rumput, tumbuhan dan bunga yang asli. Anak dapat berinteraksi melalui nyanyian alam dan berjalan melewati taman dan pohon-pohonan. Banyak hal-hal yang dapat dikenalkan pada anak tentang alam (Miller, 2009:58).

Bahan alam yang digunakan sangat beragam dan penggunaan yang dilakukan diharapkan tepat sesuai dengan keadaan lingkungan disekitar anak. Banyak langkah-langkah yang digunakan dalam penggunaan bahan alam. Adapun langkah untuk menggunakan bahan alam, yaitu bahan alam dilakukan dengan mengelompokan bahan alam berdasarkan jenis, warna, ukuran dan bentuk. Selanjutnya dicocokkan yang terlihat sama seperti ukuran atau warnanya. Disediakan bahan-bahan pendukung yang bisa dikombinasikan dengan bahan alam seperti menggunakan tangkai se- 
bagai kaki atau tangan. Kemudian dilanjutkan dengan menyusun objek bahan alam dengan menggunakan lem dan bahan-bahan pendukung lainnya (Department Education, Training and Employment, 2012:2) . Orang dewasa bisa membantu anak untuk meningkatkan kreativitas dengan memberikan kesempatan pada anak untuk mengumpulkan bahan alam. Beragam bahan yang berasal dari alam digunakan dan memiliki bermacam-macam jenis.

Keuntungan dari penggunaan media bahan adalah tidak mengeluarkan biaya yang mahal, bahkan tidak mengeluarkan biaya sama sekali. Selain itu bahan-bahan yang dibutuhkan mudah didapat. SPenggunaan media ini mendukung anak memulai belajar, menstimulasi imajinasi, mudah untuk mengingat tentang pengalaman yang bermakna dan membangun komunikasi (Isenberg \& Jalongo, 2010:279). Selain itu mendekatkan anak pada alam akan membuat mengembangkan kecerdasan naturalis anak dan anak akan dekat dengan alam. Alam menyediakan banyak hal yang dapat dipelajari. Seperti anak dapat langsung belajar mengenai tanaman, hewan, tanah, batu, dan sebagainya.

\section{METODE PENELITIAN}

Metode yang digunakan dalam penelitian ini adalah penelitian tindakan. Metode penelitian tindakan menggunakan model dari Kemmis dan Mc Taggart. Tahapan penelitian tindakan menurut Kemmis dan Taggart dalam Arikunto mencakup: (a) Perencanaan (planning), (b) tindakan (acting), (c) observasi (observing), (d) refleksi (reflecting). Kemudian berlanjut dengan perencanaan ulang (replanning), tindakan, observasi dan refleksi untuk siklus berikutnya, begitu seterusnya sehingga membentuk suatu spiral.

Penelitian ini dilaksanakan di PAUD Bestari, Gunungsindur, Bogor, pada bulan November 2012. Subjek penelitiannya adalah anak PAUD Bestari yang berusia 5-6 tahun sebanyak 11 anak.

Rancangan tindakan penelitian ini sebagai berikut. Pertama, Persiapan Perencanaan yang terdiri dari; a) mengajukan surat ijin penelitian; b) mencari dan mengumpulkan informasi atau data anak yang menjadi subjek; c) menentukan waktu pelaksanaan penelitian siklus; d) mempersiapkan rancangan kegiatan.

Kedua, perencanaan, yang terdiri dari; a) perencanaan umum, yaitu merencanakan waktu pembelajaran, rancangan pembelajaran serta instrumen pemantau tindakan, pengumpulan data dan evaluasi hasil belajar secara keseluruhan, dan b) perencanaan khusus, yaitu mempersiapkan format catatan lapangan, menentukan indikator keberhasilan dan menyiap- kan media yang akan digunakan, serta menyiapkan alat pengumpul data berupa pedoman observasi dan kamera.

Ketiga, tindakan, yang terdiri dari; a) membuat rencana kegiatan pembelajaran dan satuan kegiatan harian; b) melaksanakan kegiatan pembelajaran.

Keempat, observasi atau pengamatan tindakan, yang digunakan adalah observasi yang dilakukan untuk mengamati perilaku anak terhadap tindakan yang diberikan dilakukan bersama peneliti dan kolabolator.

Kelima, refleksi, menganalisis hasil pengamatan terhadap kegiatan penggunaan media bahan alam yang dilakukan oleh peneliti dan menganalisis data tentang kreativitas anak setelah tindakan.

Adapun kisi-kisi instrumen kreativitas anak usia 5-6 tahun di PAUD Bestari, Gunungsindur, Bogor sebagai berikut: (1) person (keterbukaan terhadap pengalaman, kemampuan menilai situasi, kemampuan untuk bereksperimen), (2) press (internal dan eksternal), (3) process (persiapan, inkubasi, iluminasi dan verifikasi), dan (4) product (original). instrumen ini menggunakan expert judgement, judgement pada ahli bidang kreativitas yang benar-benar paham tentang indikator yang hendak diamati.

Setelah data diperoleh, maka selanjutnya data tersebut dianalisis dengan teknik deskriptif kualitatif.

\section{HASIL PENELITIAN}

Hasil observasi kreativitas anak pada prapenelitian menunjukkan bahwa kreativitas anak usia 5-6 tahun di PAUD Bestari, Gunungsindur, Bogor masih belum berkembang secara optimal. Hal ini dapat dilihat dari masih rendahnya skor yang diperoleh anak.

Tabel 1 menunjukkan bahwa Hasil pengamatan yang ditemukan terkait dengan kreativitas melalui penggunaan media bahan alam di PAUD Bestari, Gunungsindur, Bogor selama prapenelitian ditemukan bahwa kegiatan pembelajaran yang diberikan oleh guru kurang menarik dan merangsang kreativitas anak, sehingga kreativitas anak belum terlihat secara optimal. 
Tabel 1. Data Hasil Penelitian

\begin{tabular}{|c|c|c|c|}
\hline \multirow{2}{*}{\begin{tabular}{c} 
No. $\begin{array}{c}\text { Respon- } \\
\text { den }\end{array}$ \\
\cline { 2 - 4 }
\end{tabular}} & Pra Siklus & Siklus 1 & Siklus 2 \\
\hline 1. & $39.8 \%$ & $56.8 \%$ & $79.5 \%$ \\
\hline 2. & $41.5 \%$ & $60.2 \%$ & $84 \%$ \\
\hline 3. & $37.5 \%$ & $65.9 \%$ & $90.5 \%$ \\
\hline 4. & $35.8 \%$ & $60.2 \%$ & $82.7 \%$ \\
\hline 5. & $43.7 \%$ & $75.1 \%$ & $97 \%$ \\
\hline 6. & $27.5 \%$ & $38.5 \%$ & $61.1 \%$ \\
\hline 7. & $37.5 \%$ & $53.1 \%$ & $78 \%$ \\
\hline 8. & $42 \%$ & $70.5 \%$ & $94 \%$ \\
\hline 9. & $31.8 \%$ & $52.7 \%$ & $70 \%$ \\
\hline 10. & $43.7 \%$ & $67.6 \%$ & $91 \%$ \\
\hline 11. & $43.7 \%$ & $60 \%$ & $81.3 \%$ \\
\hline Rata-rata & $38.6 \%$ & $60.1 \%$ & $82.6 \%$ \\
\hline
\end{tabular}

Setelah dilakukan perencanaan, tindakan dan pengamatan, peneliti bersama kolabolator mengadakan refleksi tindakan yang telah dilakukan pada siklus I, yaitu sebanyak tujuh kali pertemuan. Peneliti bersama kolabolator melaksanakan kegiatan sesuai dengan perencanaan yang telah dirancang sebelum pelaksanaan kegiatan. Setiap akhir akhir pelaksanaan pertemuan, peneliti dan kolabolator mengadakan refleksi setiap selesai melaksanakan kegiatan. Refleksi ini dilakukan dengan tujuan untuk melihat proses pembelajaran dan dampak yang terjadi pada anak. Setelah dilaksanakan tindakan siklus I, peneliti dan kolabolator memutuskan untuk melanjutkan pada siklus berikutnya. Hal ini dikarenakan kreativitas anak melalui penggunaan media bahan alam belum mencapai kriteria keberhasilan yang telah ditentukan.

Kreativitas anak dalam penggunaan media bahan alam terlihat meningkat dari pra siklus ke siklus 1. Persentase yang didapat dari siklus 1 adalah $60.1 \%$ atau jika dirata-ratakan persentase kreativitas anak meningkat hingga $21.4 \%$ setelah diberikan tindakan penggunaan media bahan alam. Persentase yang didapat pada siklus 1 ini belum mencapai target yang ditetapkan sebelumnya yaitu $71 \%$. Rata-rata persentase kenaikan siklus 2 pada setiap anak meningkat hingga $82.6 \%$ atau sebesar $22.6 \%$. Hal ini dapat dikatakan bahwa indikator kreativitas anak berada dalam tahap berkembang atau konsisten. Berdasarkan data tersebut maka peneliti memutuskan untuk tidak melanjutkan tindakan ke siklus berikutnya. Hasil pemantauan peneliti dan kolabolator menunjukkan bahwa persentase kenaikan yang terjadi pada setiap siklusnya dapat dikatakan signifikan. Maka dari itu, tindakan akan dihentikan sampai siklus 2 .

Berdasarkan pengamatan yang dilakukan pada siklus 1 dan 2 secara kuantitatif, diperoleh persentase kenaikan kreativitas anak melalui penggunaan media bahan alam. Persentase kenaikan keseluruhan sebagai berikut: responden 1 sebesar $39.7 \%$, responden 2 sebesar $42.5 \%$, responden 3 sebesar $53 \%$, responden 4 sebesar $46.9 \%$, reponden 5 sebesar $53.3 \%$, responden 6 sebesar $33.6 \%$, responden 7 sebesar $40.5 \%$, responden 8 sebesar $52 \%$, responden 9 sebesar $38.2 \%$, responden 10 sebesar $47.3 \%$, dan responden 11 sebesar $37.6 \%$

Dapat telihat persentase tertinggi adalah responden 3 dan presentase terendah adalah responden 6. Jika dilihat dari pertemuan siklus 1 dan 2 , responden 3 mengalami peningkatan disetiap pertemuan. Kepercayaan diri responden 3 semakin terlihat ketika sedang menggunakan bahan alam yang ia akan gunakan untuk menghasilkan produk. Responden 3 dapat mengekplorasi bahan alam yang akan ia gunakan. Responden 3 menghasilkan produk yang berbeda dari sebelumnya. Resonden 3 juga terlihat semakin konsisten dalam bekerjasama dengan temannya. la membantu dan memberikan pendapat kepada teman kelompoknya. Hal ini berbeda dengan yang ditunjukkan oleh responden 6 . Responden 6 tidak begitu menunjukkan peningkatan yang tajam. Responden 6 lebih sering meminta bantuan peneliti, meskipun peneliti telah memberikan motivasi agar responden 6 mau mengerjakannya sendiri.

Rata-rata anak mengalami peningkatan kreativitas sebesar $44.1 \%$. Hal tersebut terlihat dari kemampuan yang ditunjukkan anak selama pemberian tindakan sesuai dengan indikator kreativitas berdasarkan 4P yaitu, anak antusias membicarakan hal baru, anak dapat bekerjasama dalam kelompok dengan baik, anak mengikuti kegiatan dengan bersemangat, anak mengolah media yang telah disediakan, anak mampu mengolah media yang telah disiapkan, anak aktif mengajukan pendapat, anak berani maju ke depan kelas, anak memberikan ide tambahan pada hasil karyanya, anak mengenalkan hasil karyanya pada teman-teman, anak menjelaskan hasil karyanya secara detail, anak menciptakan produk sesuai dari idenya sendiri dan anak menghasilkan produk dengan bentuk yang berbeda dari sebelumnya.

Dari hasil pengamatan yang dilakukan pada siklus 1 dan 2, kegiatan penggunaan bahan alam berjalan sesuai dengan perencanaan sebelumnya. Jika dilihat dari pra siklus, masih ada anak yang malu-malu bercerita teman-temannya, ketika anak menjawab masih ragu-ragu berpendapat. Anak-anak juga kurang bersemangat dan antusias selama kegiatan pembelajaran berlangsung.

Jika dibandingkan dengan siklus pertama, anak 
terlihat mulai antusias dengan kegiatan pembelajaran. Kegiatan yang peneliti berikan sebelumnya hanyalah sebatas mengerjakan majalah untuk melatih anak membaca, menulis dan berhitung. Peneliti kurang memberikan kegiatan yang dapat mengasah kreativitas anak. Dari hasil siklus 1, dapat ditemukan ketika anak ragu-ragu dalam mengungkapkan pendapatnya, namun karena peneliti mencoba memberikan dorongan pada anak untuk menuangkan pendapat ataupun idenya. Peningkatan disiklus 1 semakin terlihat ketika anak mencoba untuk memberikan tambahan ide dari hasil karya. Anak mencoba untuk menghasilkan sebuah produk yang berbeda dari yang dicontohkan oleh peneliti. Secara kualitatif dapat dikatakan bahwa kreativitas anak dengan penggunaan bahan alam semakin meningkat pada setiap siklusnya. Berdasarkan penjelasan diatas, dapat disimpulkan bahwa kreativitas dapat ditingkatkan melalui penggunaan bahan alam.

Hasil analisis data kualitatif membuktikan bahwa penggunaan media bahan alam dapat meningkatkan kreativitas anak, salah satunya terlihat dari pribadi anak, seperti anak antusias untuk mengikuti kegiatan pembelajaran secara aktif. Dalam setiap pertemuan kepercayaan diri setiap anak perlahan mulai terlihat seperti ketika menceritakan hasil karyanya didepan temannya dengan baik. Anak juga terlihat aktif selama kegiatan pembelajaran berlangsung, seperti keingintahuan anak dengan bahan alam yang peneliti bawa membuat anak senang bertanya dan bereksplorasi menggunakan bahan alam yang ada. Berdasarkan pendapat Roger dalam Munandar yang mengatakan bahwa terdapat tiga kondisi dari pribadi yang kreatif. Keterbukaan anak terhadap pengalaman terlihat ketika anak menceritakan pengalaman liburannya bersama keluarga. Kemampuan menilai situasi sesuai dengan keadaan dia berada. Seperti terlihat ketika anak aktif bertanya atau menjawab pertanyaan yang diajukan oleh peneliti. Bisa dilihat juga ketika anak sedang berdiskusi dengan teman kelompoknnya untuk menghasilkan sebuah ide bersama. Kemampuan untuk bereksperimen dapat terlihat ketika anak sedang mengolah bahan alam atau melakukan kegiatan eksplorasi pada bahan alam yang telah peneliti sediakan untuk membuat karya.

Jika dilihat dari pertemuan yang telah dilaksanakan, penggunaan kegiatan bahan alam membuat anak termotivasi. Roger dalam Munandar mengungkapkan bahwa dorongan merupakan motivasi primer untuk kreativitas ketika individu membentuk hubunganhubungan baru dengan lingkungannya dalam upaya menjadi dirinya sepenuhnya. Dorongan tidak hanya diberikan dari luar seperti keluarga dan sekolah, namun anak dapat mendorong dirinya sendiri untuk menghasilkan sebuah ide atau karya. Dengan dorongan yang menarik didalam setiap pertemuan maka akan termotivasi untuk berkreasi dengan berbagai media seperti bahan alam dan mengikuti kegitaan dengan aktif. Selain media, peneliti memberikan dorongan secara internal seperti menghargai karya anak dan memuji hasil karyanya.

Kreativitas dapat meningkat dengan adanya proses. Proses didapat ketika anak mendapatkan kegiatan yang menarik dan kreatif. Seperti ketika anak memperlihatkan keaktifannya dalam setiap pertemuan, kemudian bersemangat dalam mengeluarkan pendapat dan aktif dalam berdiskusi. Wallas menyatakan bahwa proses kreatif meliputi empat tahap yaitu: 1) persiapan, 2) inkubasi, 3) iluminasi, dan 4) verifikasi. Dalam tahap persiapan, anak mengeksplorasi bahan alam yang telah disediakan seperti daun-daunan, biji-bijian dan ranting. Pada tahap inkubasi, dimulai proses pemecahan masalah dengan berdiskusi dengan teman kelompoknya atau saling bertukar pendapat. Di tahap iluminasi, anak akan mendapatkan idea atau gagasan untuk memecahkan masalah, kemudian didiskusikan kembali untuk dijadikan sebuah karya. Di tahap akhir adalah verifikasi, dimana anak dan peneliti bersamasama mengevaluasi kegiatan yang telah dilakukan.

Produk adalah dimensi kreativitas yang terakhir. Orang yang kreatif mampu menciptakan produk yang berdasarkan hasil pemikirannya sendiri. Anak mampu membuat produk dengan memanfaatkan bahan alam yang telah disediakan oleh peneliti. Abdulssalam mengatakan bahwa produksi kreatif adalah suatu produksi yang baru dan yang tiada tandingannya, serta dikenal dengan kemampuan untuk memproduksi sesuatu yang baru atau menciptakan hubungan baru terhadap sesuatu yang telah diketahui sebelumnya. Produk yang dihasilkan anak tidak hanya menempel dan menggunting, anak melukis diatas daun dan mencap daun. Pembelajaran yang menarik mengajak anak terus berkreasi untuk menghasilkan sebuah produk yang imajinatif.

Peneliti memberikan tindakan pada setiap pertemuan melalui penggunaan media bahan alam. Peneliti membahas mengenai tema dan dilanjutkan dengan mengenalkan pada anak-anak mengenai bahan alam yang peneliti bawa. Kemudian peneliti mengajak anak untuk membuat kreasi dengan menggunakan bahan alam yang telah peneliti sediakan. Selesai berkreasi anak diminta untuk menceritakan hasil karyanya didepan teman-temannya. Bahan alam sangat beragam dan persediaannya tersedia dilingkungan sekitar anak mapun sekolah. Peneliti pun menggunakan ranting, 
daun, batu-batuan dan biji-bijian untuk dipakai dalam kegiatan. Dalam setiap kegiatan penggunaan, bahan alam ini dilakukan agar anak bebas berkreasi dengan mengeksplorasi bahan alam yang saat itu digunakan. Bahan alam dikreasikan dengan bebas sesuai dengan kreativitas guru, sehingga pembelajaran yang disampaikan menarik dan merangsang rasa ingin tahu anak.

Peneliti menemukan kelebihan dan kelemahan dalam penggunaan bahan alam yang dilakukan dalam pembelajaran. Kelebihan yang didapat dari bahan alam adalah mudah didapat di lingkungan sekitar. Daun-daunan, biji-bijian, batu dan ranting yang peneliti gunakan berasal dari lingkungan sekitar, sehingga tidak memerlukan biaya yang besar. Selain itu bahan alam seperti daun dan biji yang memiliki bentuk dan tekstur yang beragam dan bervariasi. Guru dapat memanfaatkan bahan alam sesuai dengan kegiatan pembelajaran.

Kelemahan dari penggunaan bahan alam adalah tidak tahan lama di simpan, seperti daun yang peneliti kumpulkan cepat mengering dan mengkerut sehingga tidak dapat digunakan. Selain itu biji-bijian juga tidak dapat disimpan dalam waktu yang lama karena cepat berjamur dan harus sering dibersihkan jika masih digunakan untuk jangka waktu yang lama. Guru harus pintar dalam mengolah media bahan alam yang cepat berubah baik bentuk maupun warna.

Berdasarkan uraian diatas, maka dapat dikatakan bahwa penggunaan media bahan alam dapat meningkatkan kreativitas anak. Penggunaan media bahan alam ini ditemukan bahwa kreativitas pada masing-masing anak terlihat ketika guru memberikan dorongan yang memacu kreativitas anak. Keseluruhan aspek mengalami peningkatan selama 11 kali pemberian tindakan dilakukan. Hal ini terlihat berdasarkan 4P, yaitu person, anak menunjukkan pribadi yang kreatif karena mendapatkan dorongan (press) dari orang-orang disekitar anak dan lingkungan belajarnya. Kemudian anak mengalami proses (process) kreatif, melalui tahap persiapan, inkubasi, iluminasi dan verifikasi, sehingga menghasilkan sebuah produk (product) yang baru maupun hasil dari kombinasi ide sebelumnya.

\section{PENUTUP}

Berdasarkan hasil analisis data pada pra penelitian didapat presentase sebesar $38.6 \%$, sedangkan pada siklus 1 didapat persentase sebesar $60.1 \%$. Berdasarkan data tersebut dapat dikatakan bahwa persentase dari pra peneltianke siklus 1 mengalami peningkatan pada indikator secara keseluruhan sebesar $21.5 \%$. Seperti yang disampaikan pada interpretasi hasil analisis bahwa penelitian ini dikatakan berhasil jika adanya peningkatan sebesar $71 \%$, maka penelitian siklus 1 ini belum dapat dikatakan berhasil karena persentase kenaikan yang didapat sebesar $60.1 \%$.

Berdasarkan hasil penelitian secara kualitatif terlihat adanya peningkatan kreativitas anak usia 5-6 tahun melalui pemberian tindakan berupa penggunaan media bahan alam. Penggunaan media bahan alam digunakan dalam kegiatan pembelajaran yang menarik dan bervariasi, sehingga anak dapat terlibat secara aktif dalam setiap pembelajaran. Anak diberi kesempatan mengajukan ide dan berkreasi dengan menggunakan bahan alam yang telah disediakan. Berdasarkan hasil observasi berupa catatan lapangan, catatan dokumentasi dan catatan wawancara dapat dilihat bahwa penggunaan media bahan alam dapat meningkatkan kreativitas anak usia 5-6 tahun di PAUD Bestari Gunungsindur, Bogor.

\section{Saran}

Pertama, bagi guru kegiatan pembelajaran melalui penggunaan media bahan alam dapat dijadikan alternatif untuk meningkatkan kreativitas. Kreativitas merupakan salah satu yang perlu diperhatikan. Kegiatan penggunaan bahan alam tidak hanya digunakan untuk meningkatkan kreativitas anak tetapi dapat dimodifikasi agar dapat mengajarkan anak untuk mengembangkaan kemampuan lainnya.

Kedua, bagi Kepala Sekolah PAUD Bestari, dapat menggunakan media bahan alam sebagai media pembelajaran yang dapat meningkatkan kreativitas anak. Dalam rangka meningkatkan kualitas proses pendidikan dan pembelajaran di sekolah.

Ketiga, bagi orang tua dapat membantu pihak sekolah dalam meningkatkan kreativitas anak di rumah. Dengan membuat berbaga kreasi produk yang dapat dilakukan dirumah, sehingga membuat berbagai kreasi produk yang dapat dilakukan di rumah, sehingga mempererat hubungan orang tua dengan anak tetap terangsang kreativitasnya.

Serta yang keempat, bagi peneliti selanjutnya dapat melakukan penelitian yang berkaitan dengan kegiatan pembelajaran dengan menggunakan media yang tidak hanya berasal dari alam, tetapi dapat menggunakan barang bekas atau daur ulang. Bahan daur uang tersebut dapat berupa koran atau kertas bekas, kerdus, aqua gelas, sedotan plastik, dan kain perca. Media ini dapat digunakan pada kegiatan pembelajaran dalam rangka meningkatkan kreativitas anak usia dini.

Jurnal IImiah VISI P2TK PAUD NI - Vol. 8, No.1, Juni 2013 


\section{DAFTAR PUSTAKA}

Safaria, T. (2005). Creativity quotient. Jogjakarta: Platinum.

Abdussalam, A. (2005). Mengembangkan kreativitas anak. Jakarta: Pustaka Al-Kautsar.

Bruce, T. (2004). Cultivating creativity in babies, toddlers and young children. London: Hodder Education.

Duffy, B. (2006). Supporting creativity and imagination in the early years. New York: Open University Press.

Munandar, U. (2009). Pengembangan kreativitas anak berbakat. Jakarta: Rineka Cipta.
Whittaker, H. (2004). Accesing series sciences in action 2 (6-7) volume 2. UK: Folen Publisher.

Miller, D.L. (2009). Young children learn through authentic play in a nature explore classroom. Diakses dari situs http://www.dimensionsfoundation. org/research/authenticplay.pdf

Isenberg, J.P.,\& Jalongo, M.R. (2010). Creative thinking and arts-based learning. New Jersey: Pearson.

Department of Education. (2012). Training and employment (everyday and natural materials). Diakses dari situs www.qld.gov.au/kindy. 